\title{
ARCHAEOLOGICAL
}

\section{REPORTS FOR i $969-70$}

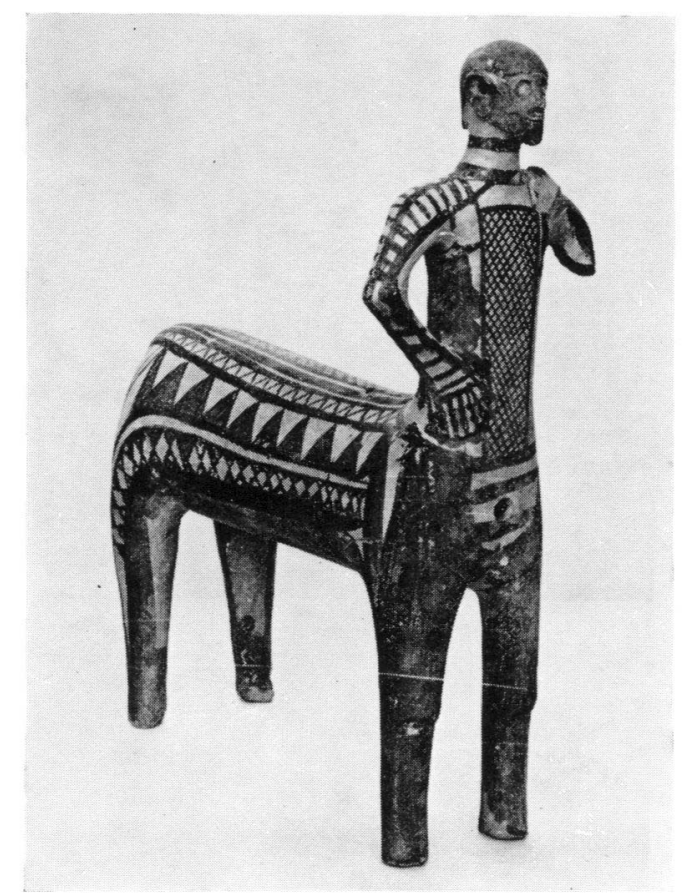

\author{
CONTENTS \\ ARCHAEOLOGY IN GREECE, I969-70 P. M. Fraser \\ ARCHAEOLOGY IN SOUTH ITALY AND SICILY, I967-rg69 \\ A. D. Trendall
}

THE GREEK MUSEUM, THE UNIVERSITY OF NEWCASTLE UPON TYNE B. B. Shefton

\begin{abstract}
PUBLISHED BY THE COUNCIL OF THE SOCIETY FOR THE PROMOTION OF HELLENIC STUDIES
\end{abstract} AND

THE MANAGING COMMITTEE OF THE BRITISH SCHOOL OF ARCHAEOLOGY AT ATHENS

I 970 


\section{CONTENTS}

PAGE

Fraser, P. M. . . $\quad \ldots \quad$ Archacology in Greece, $1969-70 \quad \ldots \quad \ldots \quad \ldots \quad \ldots \quad 3$

Trendall, A. D. $\quad \ldots \quad \ldots \quad$ Archacology in South Italy and Sicily, $1967-69 \quad \ldots \quad 32$

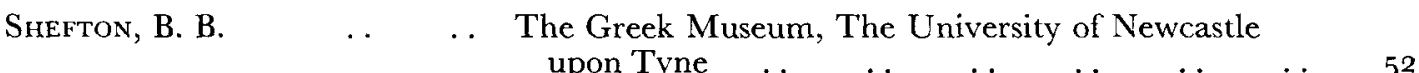

These Archaeological Reports are published by the Hellenic Society and the British School at Athens for their subscribers. They are also offered for sale to the public (obtainable from The Editor (Reports), Hellenic Society, 3I-34 Gordon Square, W.C.I) at the price of I2/6 $\left(62 \frac{1}{2} \mathrm{p}\right)$, postage paid. 'Archaeology in Greece' is an annual feature, and the occasional reports on work in other parts of the Greek world include South Italy and Sicily (this year), Cyprus, Asia Minor, the Black Sea, etc. In addition there are regular bulletins illustrating new acquisitions by museums in Great Britain.

The picture on the cover is of a barrel-shaped figurine of a centaur, of the Geometric period, from the British excavations at Lefkandi. See p. 9 . 